2021, Volume 16, ATEE 2020 - Winter Conference. Teacher Education for Promoting WellBeing in School. Suceava, 2020, pages: 285-304 |

https://doi.org/10.18662/lumproc/atee2020/19

\section{Pedagogical \\ Diagnostics at the Stage of Preparing a Child for School in Poland}

\section{Khrystyna MYKYTEICHUK1 \\ Lyudmyla TYMCHUK² Valentyna ZVOZDETSKA 3*}

${ }^{1}$ Yuriy Fedkovych Chernivtsi National University, Chernivtsi, Ukraine, k.mykyteichuk@,chnu.edu.ua

${ }^{2}$ Yuriy Fedkovych Chernivtsi National University, Chernivtsi, Ukraine, l.tymchuk@chnu.edu.ua

${ }^{3}$ Yuriy Fedkovych Chernivtsi National University, Chernivtsi, Ukraine, v.zvozdetska@.chnu.edu.ua

* Corresponding author.
Abstract: The current tendency of the European educational strategy on the compulsory children's involvement in the preschool education before elementary school raises the issue of preparing children for school and the preschool education functioning, modernization and updating the content and technology of pedagogical activities at this stage. The article highlights the innovation of the Polish theory and practice in preparing a child for school i.e. the transfer of the pedagogical diagnosis function in school readiness from psychologists to preschool teachers. The organization of systematic, daily observation and interpretation of children's activities has become an integral part of the teacher's work. The essence of systematic pedagogical diagnostics of school readiness in Polish preschool institutions is revealed. On the basis of retrospective analysis, it is highlighted the evolutionary development in Polish pedagogy of the diagnosing children's readiness problem in school. According to the chronological principle, diagnostic methods are systematized; their semantic and procedural aspects are characterized. It is substantiated that as a result of diagnostic techniques, mastering the tools and ability to perform diagnostic procedures, the teacher gets the opportunity to determine the degree of mental and social development of the child, which contributes to school tasks, as well as factors that determine this development. The teacher forms a complex child's profileconcerningthe knowledge and competencies, and on its basis develops a strategy of pedagogical influence and interaction with the child at the beginning of school.

Keywords: preschool education, school preparation, pedagogical diagnosis of readiness for school, diagnostic methods

How to cite: Mykyteichuk, K., Tymchuk, L., \& Zvozdetska, V. (2021). Pedagogical Diagnostics at the Stage of Preparing a Child for School in Poland. In O. Clipa (vol. ed.), Lumen Proceedings: Vol. 16. ATEE 2020 - Winter Conference. Teacher Education for Promoting Well-Being in School. Suceava, 2020 (pp. 285-304). Iasi, Romania: LUMEN Publishing House. https://doi.org/10.18662/lumproc/atee2020/19 


\section{Introduction}

\subsection{The chapter of introduction}

In the educational policy of modern European countries, much attention is paid to the integration processes in preschool and school education, improving the preschool education level and quality and preparing children for school as the most important factor in their further educational path.

The obligation to involve children in preschool education before elementary school is one of the EU goals, defined in the European cooperation strategic framework within education and training (Eurostat, 2013). Organizationally, this preschool education stage is represented in almost all European countries through their respective national forms (Kozak, 2017). Thus, in Germany, Austria and Switzerland, the function of the preschool level is fulfilled by "preparatory groups or classes" in kindergartens or elementary schools, depending on the child'sdifferent readiness level to learn (Eurydice Unit, 2003). In France, various forms of the preschool and elementary classes integration are used, for example, the older group of children in the mother school (4-5 years), combined with the first year of the elementary school, that is a "preparatory class" (Eurydice Unit, 2008). In Finland, this role is performed by preschool groups for 6 years old children; in Italy it is "preparation year for school" in kindergarten ("school for children"). In Poland, these are zero classes at schools ("zerówka") or preparatory groups in kindergartens, mandatory for 5-6-yearold children who will go to school in a year (European Commission, 2010).

In Ukraine, since 2010, preschool education is mandatory for fiveyear-old children and can be carried out in different types of preschools, in educational complexes "preschool - elementary school", in groups of fiveyear-old children at the Centers for child development and secondary schools (On Amendments, 2010). Its meaning is to "ensure easy adaptation of the child to the new social center i.e. school, to be one of the ways to equalize the starting opportunities of children from different social groups and the population strata; talents development, children's abilities to master new, more complex material; ensuring the psychological readiness formation 
to attend school with all its components; if necessary, to correct certain disorders and deviations in the physical, psychological, mental, emotionally motivational and communicatively verbal development of children"(Bogush, 2017).

\subsection{The research gap}

The introduction of compulsory preschool education requires the new content development in education and upbringing the five-year-old children, innovative technologies for its implementation, as well as actualizes the problem of updating the content and methods of pedagogical activities at this stage.

In this context, the foreign countries experience, where preschool education has become popular, seems interesting. Concerning the geographical and cultural neighbourhood of our country to Poland, the vector of our study is aimed at Polish theory and practice of preparing children for school.

The focus of this publication is an aspect that is a consequence of modernization processes in Polish preschool education. In accordance with the requirements of the Basic Program of Preschool Education in 2008, the task of preschool teachers is to systematically diagnose the child's readiness for school (Guz, 2010).

\section{Research questions/aims of the research}

The key role in the diagnosis of school readiness belongsnot to the counseling centers psychologists (which is typical, in particular, Ukrainian practice), but to educators i.e. preschool institutions teachers. According to E. Gruszczyk-Kolczyńska and E. Zielińska, well-known experts in this field in Poland, under such conditions "observation and interpretation of children's activities have gained meaning and practical significance" (Gruszczyk-Kolczyńska \& Zielińska, 2011). In addition to the tasks of the curriculum and the implementation of traditional educational, training and developmental goals, the teacher meetsthe systematic pedagogical observation that is to study the child in dynamics and on this basis to create an adequate system of support and development (Guz, 2010). Thus 
diagnostics is a determining factor in the content and organization of preschool education, pervading this process.

So, the purpose of the publication is to substantiate the pedagogical diagnostics innovation of child's school readiness in Polish preschool institutions.

The task is to reveal the essence, to specify and characterize the technological and semantic aspects of pedagogical diagnostics, which are carried out by Polish teachers at the preparing children for school stage.

\section{Research methods}

\subsection{Participants}

The problem of preparing children for school in modern Ukrainian science is represented by a large number of diverse studies. In the thesis by V. Prokopenko (2002) the attention focuses on the preparation technology of six-year-old children for educational and cognitive activities at school in the educational complex "preschool - secondary school - gymnasium". The range of applied issues for preparing children for school in the conditions of the educational complex "preschool institution-school" (continuity of game forms in educational activity, conditions of the child'screative development, etc.) is covered by dissertations of L. Fedorovych (2003), O. Chepka (2006), S. Ufimtseva (2007). A comprehensive theoretical analysis of the organizational and pedagogical conditions of preparing children for school with a deep scientific reflection on key concepts of the problem was carried out in the study of N. Cherepanya (2006). The dissertations of T. Bondarenko (2008) and T. Pantyuk (2018) present the historical and pedagogical perspective of preparing children for school in domestic educational practice.

In the process of scientific research different methods were used such as general scientific (analysis, systematization and generalization of scientific and theoretical materials to reveal the essence of pedagogical diagnostics; classification and analysis of the content of diagnostic methods; bibliography systematization of the researched problem); historical (chronological and retrospective for the analysis of the development in 
Polish pedagogy of the problem of the school readiness diagnosis); empirical (observational i.e. thesupervision of the kindergartens work in Polish cities).

\subsection{Materials and instruments}

In recent years, the Ukrainian bibliography has been supplemented by fundamental research on preschool education as a special link between preschool and primary school. In particular, T. Stepanova (2011) investigated the transformation of the preschool education content in the history of domestic preschool pedagogy from 1898 to 2000. Preschool education is the subject of many scientific publications such as A. Bogush (2011), N. Havrysh (2009), M. Hordiychuk (2018), T. Lesina (2017), T. Pirozhenko (2012).

Despite the fact that the issue of preparing a child for school and the functioning of the preschool level is currently under active scientific improvement, the above bibliographic digest indicates the lack of comparative research in this area. In the modern scientific space, the issues of preparation for school and preschool education in different countries of the world remain inexperienced, which actualizes the geographical direction of our scientific research shown through the publicationtitle. The training child in Poland has not yet been studied by Ukrainian scientists. Search engines reveal only two dissertations on the preparation of children for school in Poland by I. Adamek (2001) "Theory and practice of preparing children for school in the development of Polish preschool education (second half of the XIX century - 1918)" and by D. Valoshek (1999) "Formation of children's readiness for school in the Republic of Poland". Both authors are Polish scientists, but the first dissertation was defended in Ukraine, the second was in the Russian Federation.

According to the results of the numerous source base elaborations on the researched problem and direct acquaintance with work of preschool establishments in the Polish cities, we consider it necessary to emphasize high research status of the specified aspect i.e. on scales of scientific development and practical application diagnostics of school readiness, in our opinion, is a separate sphere in pedagogical theory and practice. This is confirmed by the fundamental works of a whole group of Polish researchers 
as follows B. Wilgocka-Okoń (2003), A. Szemińska (1969), L. Smółka (2010), A. Kopik (2007), D. Klus-Stańska (2004), E. Koźniewska (2006), E. Lewandowska (2011) and others.

Systematic work in the field of school maturity diagnostics began in Poland in the 1960s and continues to this day. Thus, in 1969-1970, for guidance of V. Wilgocka-Okoń (2003), research was conducted in which scientists comprehensively studied the child, his/her general health, the relationship between school maturity and children's living conditions in their family environment. Based on the results obtained, the following important statements were formulated, such as: "there is a clear dependence of the child's school readiness on the environment; it is not age that solves the school maturityproblem, but the environmental conditions associated with the child's development at school" (Wilgocka-Okoń, 2003).

The skills needed for a child to learn arithmetic, understanding the world around them, interaction and coexistence in the society are also identified (Wilgocka-Okoń, 2003).

B. Wilgocka-Okoń diagnostic tests (DS1 test) developed during the studywere widely used, aimed at checking the formation in a child the following issues:

-comparison and differentiation of things, sets and graphic characters (global, analytical and abstract);

-separation of parts from the whole, combining elements as a whole, i.e. the ability to analyze and synthesize specific objects, things and features of differentabstraction degrees (specific things, graphic features, geometric shapes);

-recognition of quantity, sets understanding, force of sets comprehension or knowledge of elementary mathematical concepts (sizesrecognition, power of setunderstanding, files comparison);

-considerations based on analytical judgments, taking into account the logical sequence of events, i.e. critical understanding based on perception and the symbolic plane (nonsense discoveryin pictures); causal considerations (arrangement according to the events sequence such as picturesque stories) (Wilgocka-Okoń, 2003). 
In 1969, A. Szemińska, together with a team of psychologists in social and educational consultations, developed a Methodology for testing school maturity, which was repeatedly used in Poland to enroll children in school a year later (Szemińska, 1969). She suggested dividing situational tasks into group and individual. Group tasks involved the execution of a drawing on a certain topic, drawing on a sample, random selection. Checking the graphic level was possible when developing a specific topic. Movement skills were assessed by observing the child's behavior in the proposed moving games. The location of the picture made it possible to determine the reasoning effectiveness. However, the effectiveness of visual analysis and synthesis was tested during the planned schemedisplay.

Individual tasks include:

-picturedescription, the purpose was to determine the ability to speak on a particular topic;

- directed conversation, the purpose is to check information about the immediate environment and natural phenomena;

-a pictorial puzzle or picture story, the purpose was to test verbal grounding;

-calculation, the aim is to test knowledge of basic numerical concepts;

-word analysis, diagnostic purpose was to determine the effectiveness of auditory analysis.

K. Dudkiewicz (1979) tried to determine whether the results of the schooling readiness test affect the further child'sacademic results. The results of her research allowed to state in the 1970s that children who achieved a high level of school readiness and in further education achieved full or partial success (Dudkiewicz, 1979).

With the implementation of the education reform in 2004, which included the compulsory schooling of six-year-old children, A. Kopik and her team conducted a study aimed at diagnosing the preparation of six-yearold children for compulsory secondary education. The following areas were investigated and analyzed:

-children's health i.e. physical health, mental health, state of medical and psychological-pedagogical care; 
-physical development (height and weight, chest circumference, shoulders and waist, nutritional status) and motor activity;

-physical training development i.e. coordination skills: movement speed and sense of balance; static skills: abdominal muscle strength, explosive force of the lower extremities; strength of arms and shoulders, movementspeed; movement skills i.e. throwing and catching, pushing, jumping, running;

-mental development i.e. comparing objects, separating part from the whole, determining the number, speculations based on analytical judgments. The results were divided into four groups, illustrating readiness to read, write, count, and think. The research area also included some general learning skills: general knowledge, auditory and visual analysis and synthesis, comprehension of the read text;

-social and emotional development i.e. the independence development, initiative in friendly contacts, compliance with norms and rules, the ability to cooperate in a group, attitude to tasks (Kopik, 2007).

The starting point for the study conducted by D. Klus-Stańska was the understanding of the school education beginning as one of the special periods that requires a great mobilization of adaptive capabilities of the individual. The family environment and the environment of the institution were recognized as important factors in preparing six-year-old children for school (Klus-Stańska, 2004).

The author, writing about the school adaptation of first-graders, suggested looking thoroughly at the seven-year-old pupilrole. The results of research on children's adaptation to school show, in particular, that the modern school focuses on the activities of the child that the teacher expects; this is established by assessments system and praise from the educator regarding the competition and independence of the child in achieving the stated goals. The study is grounded on the understanding that the student's activity based on class participation depends on the family ethos, i.e. socioeconomic and cultural status, parents'education, residence, language of school and family; the child's health, cognitive, psychomotor and social development, as well as work style (Klus-Stańska, 2004). Accordingly, scientists argue that certain groups of children face difficulties in adapting to 
school. This is due to the school requirements and functioning, which is not adapted to their biological structures and environmental conditions (KlusStańska, 2004).

\subsection{Procedure}

Realizing the practical significance of the problem of children's school readiness, a group of researchers (A. Frydrychowicz, E. Koźniewska, A. Matuszewski, E. Zwierzyńska) in 2006 developed the School Preparation Scale (Skalę Gotowości Szkolnej - SGS) (Frydrychowic et al., 2006).

Its construction is based on three important assumptions. It was assumed that school readiness is multidimensional, determined by the development tasks and areas of child'sactivity in the environment (Brzezińska, 1987).

The psychological and educational nature of the concept is taken into account; the content is related to both the child's development and the education system, including programs, conditions and requirements of teachers (Wilgocka-Okoń, 2003). Significant importance was also given to the motivational aspectlearning, according to which the readiness to learn is expressed in the will, interest, persistence in overcoming difficulties, achieving by the child even a small progress. Eventually, the "criterion of the child's level of development" was replaced by the "criterion of progress." The assessment of such school readiness should consider the educational, social and emotional needs of all children. However, this is of great importance for equalizing the school beginning of those children who are more difficult to meet the institutional and program requirements of the school.

The first version of the school preparation scale was developed in 2004, and numerous experiments and standardizations were conducted in the following years to determine the SGS structure. The scale consists of five parts, which relate to certain aspects of school preparation and at the same time areas of children's activities.

The first part marked with the letter A, mentioned behavioral skills and skills related to cognitive activity i.e. the child learns about the environment and himself/herself, learns to understand the world. 
Part B deals with the behavior of a child in a peer group i.e. the child plays and learns in a peer group, gains social skills.

The next part $\mathrm{C}$ focuses on the manifestations of independence / autonomy of the child and their ability to cope with problem situations that is the child learns to be independent in difficult situations.

The fourth part $\mathrm{D}$ focuses on the task the child fulfills alone or while studying under the guidance of a teacher i.e. the child is active, performs tasks, works under the guidance of a teacher.

The last, fifth, part $\mathrm{E}$ of the applied method is connected with preparation of the child for training that is the child prepares for the training beginning to read, write and count (Koźniewska, 2006). A total of 72 sentences describe children's behavior and skills, as well as the corresponding SGS subgroups.

The teacher's task is to assess the frequency of a certain behavior or skill on a four-level scale based on observations made during daily activities. This requires the teacher to read the course-book, plan the work, present the method to the parents and obtain their consent to use the scale.

The SGS scale contains six groups of subtests that identify specific components of school readiness that meet certain objectives of child development: the child's knowledge and cognitive skills, cooperation with peers, achieving independence, introducing new forms of activity - learning and work, learning to read and write (Michalak \& Misiorna, 2006).

School skills (20), the subclass includes items contained in parts A and $\mathrm{E}$ of the scale, address various aspects of a child's development i.e. focus on actions taken, understanding of causal relationships, understanding of relationships and concepts related to space, knowledge of terms related to the categories of time, performing logical and mathematical operations, performing transformations on language material, independent reading skills and performing graphomotor tasks, cyclic changes observation in nature.

Cognitive competences (12), this subclass includes elements contained in parts A and E. This subclass shows those behaviors and skills of the child that cover his/her interests and cognitive achievements, such as finding and collecting experience and sharing it to others. The skills included in this subclass are related to various areas of the child's activity, such as 
learning about the world of nature and society. It is important that the subscale of cognitive competencies contains a resource of the child's abilities that go beyond direct experience, express elements of self-knowledge and attempts at self-esteem, conscious reading skills and advanced mathematical skills.

Motor ability (8), this subscale includes competencies that are in parts B and E: physical activity and mobility / movability of the child, motor and manual coordination of movements and the child's satisfaction with participation in physical activities.

Independence / self-determination(12) is the subclass containing the elements existing in both parts $\mathrm{C}$ and $\mathrm{D}$ i.e. independent performance of activity, aspiration to solve the set task independently, self-confidence in overcoming difficult situations, inventiveness. The content of this subclass creates such characteristics of behavior as persistence and stability.

The non-conflict relationship subscale (12) contains elements mainly in Part B and one element in Part D that relate to the child's social skills: group work, taking into account the rights of other children, matching behavior with certain conditions, resolving conflict situations, ability to control strong emotions.

Social activity (9) is the subclass with elements contained in parts B and $\mathrm{D}$ and indicates the child's behavior and communication skills in general and communication with peers in particular: the ability to ask questions, collect the information, express themselves and their feelings, understand themselves and others, provide support and assistance (Michalak \& Misiorna, 2006).

Some SGS calculations indicate different aspects of a child's readiness for primary school; emphasizing the complexity of this important "stage" concerning the child's development in cognitive, motor and emotional-social spheres. The observation results of each child in six estimations make up the child's profile, which is a general picture of his/her school preparation. A formal interpretation makes it possible to refer the child's results to a verified sample of six-year-olds. A lower or lower than expected result in one of the calculations is a sign of the failure risk. Every 
child who reaches a lower or lower level than expected requires a thorough diagnosis.

It is important to note that despite the availability of well-developed diagnostic tools, in particular the SGS scale, research on a child's school readiness has continued in Poland.

In 2008, after another reform, when teaching was reintroduced at the age of six, a number of new diagnostic programs and tools were created for teachers who study five-year-old, then - during the year - work with them and diagnose in the educational process.

Thus, in 2008-2009, a study was conducted throughout Poland under the leadership of $\mathrm{H}$. Sowińska, which concerned the activities of kindergartens in the field of preparing five-year-old for school education and studying the state of competencies formation necessary for successful adaptation in school. The study was based on an extensive and carefully thought-out methodology. Among other natural observations, there are used investigations of the child's behavior in many natural situations of the educational process; and also studied the child's behavior in many specific situations, created specifically for research purposes; for the analysis of competencies, design methods and analysis of various child labor products were used (Lewandowska, 2011).

Areas of study included:

1) the effectiveness of large motility on the example of a static coordination test (standing on toes on both feet for a given period of time);

2) the efficiency in the field of small motility on the example of graphomotor tests to calculate the "wave" in accordance with the direction of writing and without taking your hands off the page and the picture of a rabbit, keeping the direction of writing without taking your hands off;

3) the level of cognitive competencies development:

-the ability to see the details in the picture,

-the ability to solve intellectual problems contained in the story "The Adventures of Gapison" (understanding of causal relationships and functional elements between the knowledge elements),

-the skills of solving practical problems in studying the features of objects during classes in kindergarten (hypotheses and practical testing), 
-the skills of proof and substantiation based on the illustrated situation;

-the generalization skills during the conversation based on their own previous experience;

-the skills to reason and draw conclusions during practical activities and to abstract during conversations, use knowledge in different situations (Andrzejewska, 2011);

4) the level of emotional competencies development:

-the level of self-esteem examined by the test,

-the ability to recognize the emotions contained in the characters,

-the ability to name the symbols represented in the diagrams,

-the emotional behavior during a conversation with an unknown person and establishing contact with him/her (start a conversation, maintain a conversation, stop the relationship) (Grzeszkiewicz, 2011);

5 ) the level of social competencies development in the educational situations is reduced to:

-the child's ability to communicate with an unknown person;

-the effectively instrumental competence is understanding in a situation consisting in joint picture drawing;

-ability to interact in a moving game "Crossing the river",

-the ability to choose a certain behavioral position when answering the teacher's questions, i.e., attention is paid to how the child behaves when answering the teacher's questions: does the child answer in turn, follows the conditions, agrees to answer, exclaims, shouts at others, pay attention to others, culturally treats a colleague) (Lubowiecka, 2011).

The study on the preparation of a five-year-old child for crossing the school border was also enriched by determining the context of the child's social development. Kindergarten educators working with the surveyed children and the organizational and material condition of institutions were studied. Analyzing the teacher, his/her work style was considering as a determinant or determining factor of competent activity in changing sociocultural conditions (child-oriented style and program-oriented style), formal and mental (mental) image of the teacher (education, career growth, forms of improvement and social activity, motives of professional development, 
perception of the profession of a kindergarten teacher, interests and dreams, perception of one's own personality), style of work in different educational situations, behavior in solving research tasks (dismissal - restrictions), style of work in evaluating and selecting children's works of art and organization of the exhibition, behavior in creating children's teams for research and physical activity (Parczewska, 2011).

Gruszczyk-Kolczyńska and Zielińska developed their diagnostic methods. Analyzing the requirements for children expected in the first grade, they proposed a certain algorithm for a comprehensive pedagogical diagnosis, which involves studying the specific qualities of children that provide them with a successful start of learning, such as self-care, motor skills, functioning during the game, acceptance and implementation of tasks (Gruszczyk-Kolczyńska \& Zielińska, 2011).

The self-care skills formation, which is determining factors in the children' readiness to attend school, are studied during three diagnostic experiments: "In the locker room", "In the bathroom", "In the room or cafe". The teacher pays special attention to "children's attitude to independent activity, correctness and degree of independence in its implementation, care for the requirement and need, helping weaker children" (Gruszczyk-Kolczyńska \& Zielińska, 2011).

\section{Results}

The teacher diagnoses children's motor skills using the experimental method "Obstacle Course", which defines the following framework:

1)social maturity that is the understanding and execution of commands (whether children are able to focus attention, whether they experience difficulties because of it; how they understand commands that hinder understanding, etc.); how to pay attention to other children, their presence (performance of motor tasks, independently from someone, cooperation with peers, helping another child when he/she needs it, etc.);

2)physical fitness is while walking (on the fingertips, feet, four limbs); overcoming the barrier; jumping on one leg; hitting the target; running to the object, walking up the stairs; 
3)participation in team games and classes (Gruszczyk-Kolczyńska \& Zielińska, 2011).

The teacher records the functioning of children during the game in the form of a chart, which is created during the method of "Sweet party for dolls and teddy bears." During the observation, the teacher can determine: the duration of the child's interest in fun, the degree of involvement in entertainment planning, ways to determine further tasks, how to communicate in the game and enjoy the fun, the children' desire and wish to tidy up after the game.

The teacher diagnoses the ability of children to accept and implement tasks during such experiments as "Sockets" and "Christmas tree chains". Based on their results, the educator receives information about the characteristics of children in the following areas:

1)organizing children to listen to a series of orders that concern a task performed individually or in a group;

2) understanding the meaning of the sentence and performing actions for its final development;

3)interacting with other children during the task;

4)satisfying from a well-performed task;

5)maintaining order during and after work (Gruszczyk-Kolczyńska \& Zielińska, 2011).

Observation and analysis of children's activities is the first stage instating the school readiness, the second is tests that demonstrate the knowledge and skills needed in school. To conduct test procedures, Polish teachers working in various forms of preschool education master a comprehensive method "Diagnosis of the child's school readiness in the last group of kindergartens", developed by J. Andrzejewska and J. Wierucka (2010). The range of diagnostics includes key competencies that determine a child's success in school, namely:

-motor activity i.e. large and small motor skills (writing); social activity, skills and self-knowledge;

-languages and communication skills;

-child's knowledge of the world;

-knowledge and skills in mathematics and reading; 
-creative activity;

-social activity and skills (according to parents);

-social activity and skills (according to the teacher) (Andrzejewska \& Wierucka, 2010).

\section{Discussions}

The methodology involves the child with the help of the teacher (during the kindergarten) a number of specific tasks: to prepare for sending an envelope from the pattern with the specified content; to make animated characters for puppet theater; to build geometric shapes according to instructions and their own choice; to pour water from a jug into a bottle using a funnel; to simulate traffic on the street with cars and pedestrians; to overcome obstacles; to complete the drawing according to a sample or their own idea; to tell by illustration, where children are depicted performing hygienic procedures in the bathroom; to analyze the content of a story and project their own behavior in such a situation; to compose stories in illustrations on the topic "Where does the name of a device come from", come up with names for different devices and objects; to draw your own character; to create a picture-mystery "Family on Sunday" and to tell how the child spends time with family; to know and understand the attributes and symbols (symbols, inscriptions, codes in these places), to complete the dialogue on the content of the illustration, filling the "gaps" between the symbols (Andrzejewska \& Wierucka, 2010).

A prescription letter entitled "Readiness criteria for up to five years" (GE-5) is also required in the diagnostic tasks of preschool and elementary school teachers. Observation of a five-year-old child takes place in the following areas: the child's attitude to the environment and himself/herself, the ability to understand the world; play and study in a group of peers, gaining social experience; ability to be independent in new difficult situations; performing tasks and activities under the guidance of a teacher; readiness for reading, writing, mathematics. The results of the observation are supplemented by data on the child's health, the choice of the dominant hand, data on interests and talents, school attendance and measures taken by the teacher (Clipa, 2014; Smółka, 2010). Observations are supplemented by 
data on the child's health, the choice of the dominant hand, data on interests and talents, school attendance and teacher actions.

\section{Conclusions}

Thus, the organization of observation and interpretation of children's activities is an integral part of the pedagogical process of preparing a child for school. A teacher in a Polish preschool should be equally an educator, a specialist in didactics and a psychologist.

Knowledge of diagnostic techniques, tools and the ability to perform diagnostic procedures allows the teacher to determine the degree of the child's mental and social development, which contributes to the tasks of the school, as well as the factors that determine this development.

Based on the diagnosis, the teacher forms a comprehensive profile of the child in terms of its knowledge and competencies, which helps to: create a descriptive characteristic of each child; identify its abilities and willingness to learn; form a holistic view of the child; explain the child's behavior and his/her attitude to themselves and others, or to the world; develop a system of support and the individual improvement, in which he/she and his/her environment will be actively involved; prepare for each parent a list of the child's skills that determine a good start in school.

Based on the results of systematic diagnosis, the teacher develops a strategy of pedagogical influence and interaction with the child, taking into account its individual differences and personal learning needs; considers the choice of forms, methods of work, didactic means; application of active methods that allow to stimulate the child to search and independent cognition. Knowledge of the opportunities, needs and interests of children helps the teacher to plan their real and objective roles in the classroom, to develop strategies and programs for early development intervention in compliance with the principles of individualization and socialization.

Pedagogical diagnosis thus becomes useful for rethinking the time and space of the child and involving the local environment in the didactic and educational process. 


\section{References}

Adamek, I. (2001). The Theory and Practice of School Preparation of Children in the Conditions of the Development of the Polish Preschool (second half of XIX century 1918) [Extended abstract of Candidate's thesis]. Kyiv.

Andrzejewska, J. (2011). Kompetencje poznawcze dzieci piecioletnich, In: H. Sowinska (Red.), Dziecko w szkolnej rzeczywistości. Założony a rzeczywisty obraz edukacji elementarnej. Poznań: Wydawnictwo Naukowe UMA.

Andrzejewska, J., \& Wierucka, J. (2010). Razem w przedsžkolu. Program wychowania przedszkolnego. Wydanie rozszerzone, Warszawa: WSiP.

Bogush, A. M. (2011). «Pre-school education» phenomenon in the system of continuous education. Nauka and osvita, 4, 6-8.

Bogush, A. M. (2017). Pre-school and primary branches of education - branches of continuity. Pedagogical education: theory and practice. Psychology. Pedagogy. Collection of scientific works, 28, 23-27.

Bondarenko, T. M. (2008). Preparation of Children for School as a Pedagogical Problem in the Theory and Practice of Home Pedagogical Science (the second half of the 20 th century) [Candidate's thesis]. Luhans'k.

Brzezińska, A. (1987). Gotowość dzieci w wieku przedszkolnym do czytania i pisania. Poznań: Wydawnictwo Naukowe Uniwersytetuim.

Chepka, O. V. (2006). The succession of the playing forms of educational activity under conditions of scientific-educational complex «school-kindergarten» [Extended abstract of Candidate's thesis]. Kyiv.

Cherepanya, N. I. (2006). The organizational and pedagogical conditions of children's preparation for school [Candidate's thesis]. Odesa.

Clipa, O. (2014) Social and Emotional Development of Pre-schoolers. In O. Clipa, M. Oliznik, \& M. Stawiak-Ososinska (Coords.), The actual Problems of the Theory and Practice of Modern Pre-School Education in Poland, Romania and Ukraine (pp. 19-33). Ed. Lumen Media Publishing.

Dudkiewicz, K. (1979). Trafnośćprognostyczna testu dojrzałości szkolnej Barbary WilgockiejOkoń. Kwartalnik Pedagogiczny.

European Commission. (2010). Structures of education and training systems in Europe. 2009/10. Finnish National Board of Education. http://daneshnamehicsa.ir/userfiles/file/Resources/183) $\% 20$ Europa/Finland EN.pdf

Eurostat. (2013). Smarter, greener, more inclusive? Indicators to support the Europe 2020 strategy Publications Office of the European Union. http://ec.europa.eu/eurostat

Eurydice Unit. (2003). Structure of education, vocational training and adult education systems in Europe. Germany 2002/ 2003. Eurydice Unit.

Eurydice Unit. (2008). Structure of education, vocational training and adult education systems in Europe. Poland 2008. EurydiceUnit. 
Fedorovych, L. O. (2003). Opening-up of Children to School in Conditions of Educational Complex [Extended abstract of Candidate's thesis]. Kryvyy Rih.

Frydrychowicz, A., Koźniewska, E., Matuszewski, A., \& Zwierzyńska, E. (2006). Skala Gotowości Szkolnej. Podręcznik. Warszawa.

Gruszczyk-Kolczyńska, E., \& Zielińska, E. (2011). Nauczycielska diagnoza gotowości do podjecia nauki w szkole. Jak prowadzić obserwację dzieci, interpretowaćw yniki i formułować wnioski. Kraków, Centrum Edukacyjne Bliżej Przedszkola.

Grzeszkiewicz, B. (2011). Kompetencje emocjonalne dzieci pięcioletnich, In: H. Sowińska (Red.), Dziecko w sqkolnej rzeczywistości. Założony a rzeczyywisty obraz. edukacij elementarnej. Wydawnictwo Naukowe UMA.

Guz, S. (2010). Wczesna edukacja dzieci - stan, potrzeba, kierunek przemian. In: S. Guz (Red.), O pomýslny start szkoolny dziecka. Warszawa: Wydawnictwo Comandor.

Havrysh, N. (2009). Problems existence, they need to be solved: the educational process models. Preschool education, 6, 7-11.

Hordiychuk, M. (2018). The contextual approach in the pre-school education organization of older preschool children. Pedagogical education: theory and practice: a collection of scientific works [Kamenets-Podolsky National University named after Ivan Ogienko], 24(1-2018), 2, 229-235.

Klus-Stańska, D. (2004). Adaptacja sækoolna siedmiolatków. Wydawnictwo Uniwersytetu Warmińsko-Mazurskiego.

Kopik, A. (2007). Széściolatki w Polsce. Raport 2006. Diagnoza badany chsfer rozwoju. Wydawnictwo TEKST.

Kozak, L. (2017). Modern preschool education: the European experience. Educational discourse, 3-4(18-19), 242.

Koźniewska, E. (2006). Skala Gotowości Szkolnej. Warszawa.

Lesina, T. M. (2017). Preschool education for children: Some aspects of the pre-school teacher vocational training to stimulate their pro-social activity [Scientific notes] [Kirovograd State Pedagogical University named after Vladimir Vynnychenko]. Series: Pedagogical Sciences, 150, 80-85.

Lewandowska, E. (2011). Poziom rozwoju sprawności motorycznej dzieci pięcioletnich. In: H. Sowińska (Red.), Dziecko w sqkolnej rz̨eçyywistości. Założony a rzeczywisty obraz edukacji elementarnej. Wydawnictwo Naukowe UMA.

Lubowiecka, J. (2011), Kompetencje społecznedzieci w sytuacjach edukacyjnych w przedszkolu. In: H. Sowińska (Red.), Dziecko w szkolnej rzeczywistości. Zatożony a rzeçywisty obraz edukacji elementarnej. Wydawnictwo Naukowe UAM.

Michalak, R., \& Misiorna, E. (Red.). (2006). Konteksty gotowości szkolnej, Centrum Metodyczne Pomocy Psychologiczno-Pedagogicznej. Warszawa. 
On Amendments the Legislative Act on General Secondary and Pre-school Education Regarding Organization of the Educational Process: Law of Ukraine of July 6, 2010 (2010). Information of the Verkhouna Rada of Ukraine, $46,545$.

Pantyuk, T. I. (2018). Social and pedagogical determinants of preparing the children for school in Ukraine: theory and practice (1945 - 2017) [Doctor's thesis]. Zhytomyr.

Parczewska, T. (2011). Strategie stosowane przezprzedszkole w realizacjij ego funkcji i zadań edukacyjnych. In: H. Sowińska (Red.), Driecko w słkolnej rzeczymistości. Założony a rzeczywisty obraz edukacji elementarnej. Wydanictwo Naukowe UMA.

Pirozhenko, T. (2012). Why does «Early Childhood» slow down? Educator methodologist of preschool institution, 7, 9-12.

Prokopenko, V. I. (2002). Preparing of the 6-years children to the study-knowledge work at the school [Extended abstract of Candidate's thesis]. Kyiv.

Smółka, L. (2010). Diagnoza w edukacji przedszkolnej. In: S. Guz, I.

Zwierzchowska (Red.), Opomýslny start szkolny dziecka. Wydawnictwo Comandor.

Stepanova, T. M. (2011). Transformation of Content of Preschool Education in the History of the National Preschool Pedagogics (end of XIX - XX centuries) [Monograph]. Kyiv.

Szemińska, A. (Red.). (1969). Zapisy do klasy pierwszej szkoly podstawowej. Warszawa PZWS.

Ufimtseva, S. V. (2007). Organization and pedagogical conditions of child's personality creative development in conditions of teaching and educational complex: pre-school institute primary school [Extended abstract of Candidate's thesis]. Kyiv.

Valoshek, D. (1999). The children's readiness for motion for school education in the Republic of Poland [Doctor's thesis]. Moskow.

Wilgocka-Okoń, B. (2003). Gotowośc sqkolna driecisze ścioletnich. Wydawnictwo Akademickie Żak. 